\title{
Meaningful Work, Job Resources, and Employee Engagement
}

\author{
Simon L. Albrecht ${ }^{1, *(1)}$, Camille R. Green ${ }^{2}$ and Andrew Marty ${ }^{3}$ \\ 1 School of Psychology, Deakin University, 3125 Melbourne, Australia \\ 2 Department of Education \& Training, 3000 Melbourne, Australia; camille.green@education.vic.gov.au \\ 3 SACS Consulting, 3000 Melbourne, Australia; andrewm@sacsconsult.com.au \\ * Correspondence: simon.albrecht@deakin.edu.au
}

Citation: Albrecht, S.L.; Green, C.R.; Marty, A. Meaningful Work, Job Resources, and Employee Engagement. Sustainability 2021, 13, 4045. https://doi.org/10.3390/ su13074045

Academic Editor: Simon Moss

Received: 18 February 2021

Accepted: 26 March 2021

Published: 6 April 2021

Publisher's Note: MDPI stays neutral with regard to jurisdictional claims in published maps and institutional affiliations.

Copyright: (c) 2021 by the authors. Licensee MDPI, Basel, Switzerland. This article is an open access article distributed under the terms and conditions of the Creative Commons Attribution (CC BY) license (https:// creativecommons.org/licenses/by/ $4.0 /)$.

\begin{abstract}
Meaningful work and employee engagement have been the subject of increasing interest in organizational research and practice over recent years. Both constructs have been shown to influence important organizational outcomes, such as job satisfaction, wellbeing, and performance. Only a limited amount of empirical research has focused on understanding the relationship within existing theoretical frameworks. For this study, meaningful work is proposed as a critical psychological state within the job demands-resources (JD-R) model that can therefore, in part, explain the relationship between job resources and employee engagement. Survey data collected from 1415 employees working in a range of organizations, across a number of industries, were analyzed with confirmatory factor analysis (CFA) and structural equation modelling (SEM). In support of expectations, job variety, development opportunities, and autonomy, each had a significant and positive direct association with meaningful work. These job resources also had a significant and positive indirect effect on employee engagement via meaningful work. Although job variety, development opportunities, autonomy, and feedback had significant positive direct associations with engagement, contrary to expectations, supervisor support had a negative association with engagement. The final model explained a sizable proportion of variance in both meaningful work (49\%) and employee engagement (65\%). Relative weights analyses showed that job variety was the strongest job resource predictor of meaningful work, and that meaningful work was more strongly associated with employee engagement than the job resources. Overall, the results show that meaningful work plays an important role in enhancing employee engagement and that providing employees with skill and task variety is important to achieving that goal. Practical implications, study limitations, and future research opportunities are discussed.
\end{abstract}

Keywords: meaningful work; work engagement; job resources

\section{Introduction}

People can spend more than half of their waking lives at work. Work can be a source of stress, dissatisfaction, and burnout, but also a source of meaning, satisfaction, and engagement [1]. Over the past twenty years, with the recognition of the importance of focusing on the positive dimensions of the employee experience [2,3], there has been an increasing researcher and practitioner focus on constructs, such as meaningful work and employee engagement. However, only a limited amount of empirical research has focused on embedding an understanding of their relationship within existing theoretical frameworks. The purpose of this paper is to examine whether meaningful work functions as a critical psychological state within the job demands-resources (JD-R) model that can, in part, explain the relationship between job resources and employee engagement. This paper therefore contributes a theoretically grounded explanation for how organizations can measure and achieve sustainable employee engagement through the provision of resources that contribute to the experience of meaningful work. Furthermore, increasingly, the role of meaningful work and employee engagement is being considered in the research and 
practice on sustainable organizational business, corporate social responsibility, and human resource practices [4-6].

With respect to meaningful work, Fletcher and Schofield ([7], p. 1) argued that the "concept of meaningfulness as a 'fundamental' psychological need that strengthens an individual's self-worth and personal agency (Kahn and Heaphy 2014; Saks 2011; Yeoman 2014) is becoming increasingly relevant to human resource management (HRM) scholars and practitioners (Bailey, Yeoman, Madden, Thompson, and Kerridge 2018; Lysova, Allan, Dik, Duffy, and Steger 2018)". Employees who experience their work as meaningful can help organizations achieve optimum and sustainable individual, team, and organizational outcomes [8,9]. Additionally, Lysova, Allan, Dik, Duffy, and Steger ([10], p. 374) argued that "organizations not only have the capacity to foster meaningful work by implementing diverse practices to create meaningful workplaces (e.g., Chalofsky 2010; Pratt and Ashforth 2003; Pratt, Pradies, and Lepisto 2013), but also that they have an ethical obligation to establish the basic moral conditions that allow such workplaces to flourish (Michaelson, Pratt, Grant, and Dunn 2014)".

With respect to employee engagement, Macey, Schneider, Barbera, and Young ([11], p. xv) noted that "rarely has a term...resonated with business executives as employee engagement has in recent years". Employee engagement has been associated with positive individual, team, and organizational outcomes, such as increased job satisfaction and wellbeing, reduced job turnover, and improved individual and organizational performance e.g., [12-15].

The benefits associated with engagement have prompted research aimed at identifying the key antecedents or "drivers" of engagement e.g., [16-19]. Although an increasing number of studies and meta-analyses have identified that job characteristics, such as job variety, autonomy, and supervisor support, as being consistently associated with engagement e.g., [20,21], less is known about the psychological mechanisms or mediators that account for the influence of job resources on employee engagement. One such important potential mediator is work meaningfulness, with researchers positing that employees who are able to draw positive affect from the meaning and purpose of their work are more likely to be engaged [22,23].

Although the conceptual relationship between employee meaningful work and engagement has to some degree been addressed in the literature e.g., [24,25], there has only been a limited amount of empirical research linking the two constructs e.g., [26-28]. It is important to accumulate evidence that sheds light on whether employees who experience a strong sense of purpose and meaning in their work are more likely to be engaged, and thereby deliver positive individual and organizational outcomes [9,29]. In this sense, meaningful work can be thought of as a critical psychological state that bridges the theoretical gap between job characteristics and engagement. The remainder of this introduction overviews and elaborates the importance of meaningful work, overviews and elaborates on the importance of job resources and employee engagement and draws theoretical linkages between the constructs.

\section{Work Meaningfulness}

Questions about the purpose and meaningfulness of life have preoccupied humankind for centuries see [30]. As previously noted, the notion of "meaningfulness at work" has gained momentum in organizational literature over the past few decades. Hackman and Oldham [31] recognized employee recognition of their work as meaningful as a necessary and important precondition to employee motivation and performance. Hackman and Oldham [32] (p. 162) defined meaningful work as the "degree to which the employee experiences the job as one which is generally meaningful, valuable, and worthwhile". Meaningfulness also refers to the amount of purpose or significance that employees attach to their work [33]. Numerous alternative definitions of meaningful work have been offered e.g., $[9,27,34,35]$. Recognizing that there is no universally agreed definition, for the purpose of the present study, meaningfulness is defined as a "positive psychological state whereby 
people feel they make a positive, important, useful contribution to a worthwhile purpose through the execution of their work" [29] (p. 238).

To in part address some "inconsistent and confusing" use of the terminology associated with meaningful work [36], it is important to embed an understanding of meaningful work within well-researched models, theories, and frameworks. Most of the research aimed at understanding and explaining the nature, antecedents, and consequences of meaningful work has drawn from needs theory e.g., [37-39], job characteristics theory [31,32], and positive psychology e.g., [40].

Job characteristics theory (JCT) [31] has provided the theoretical basis for much of the literature and research relating to meaningful work e.g., [41,42]. JCT explains that jobs with enriched job characteristics (skill variety, task variety, task identity, autonomy, and feedback from the job) result in positive work-related outcomes, such as motivation, satisfaction, performance, and decreased absenteeism [31]. Additionally, Hackman and Oldham [31] argued that three critical psychological states (meaningfulness, responsibility, and feedback) mediate the relationship between job characteristics and positive work-related outcomes. A significant body of empirical research supports the primary tenets of JCT. For example, Humphrey, Nahrgang, and Morgeson's [43] meta-analysis showed that jobs with enriched job characteristics had significant corrected meta-analytic correlations with job satisfaction (mean across the five job characteristics $p=0.41$ ), growth satisfaction (mean $p=0.55$ ), internal work motivation (mean $p=0.39$ ), supervisor satisfaction (mean $p=0.30$ ), co-worker satisfaction (mean $p=0.39$ ), compensation satisfaction (mean $p=0.19$ ), and promotion satisfaction (mean $p=0.21$ ). Research evidence, albeit not so much evidence, has also been provided that supports the proposition that enhanced job characteristics lead to greater employee experiences of meaningful work [10,31,43]. Humphrey et al. [43] (p. 1341) showed that the five job characteristics were all important antecedents of meaningfulness ( $p=0.37$ to $p=0.68$ ), and that meaningfulness was easily the strongest and "most critical" psychological state mediating the relationship between job characteristics and work-related outcomes. Indeed, Humphrey et al. [43] suggested that their results justify modifications to the job characteristics model (JCM) such that experienced meaningfulness should be modelled as the primary mediator of the influence of motivational job characteristics on work outcomes.

More recently, the job demands-resources model (JD-R) [16,22] has also been invoked as a useful framework for understanding how meaningful work emerges and how it influences downstream attitudinal, behavioral, and performance outcomes [26,29,44]. The JD-R accommodates the consideration of additional variables beyond those included in the JCM that help explain employee motivational outcomes such as engagement. Meta-analyses e.g., $[17,21,45]$ have identified that supervisor support and learning and development opportunities are important additional predictors of engagement beyond those included in JCT e.g., [46,47]. Additionally, and beyond the influence of job resources and job demands on engagement, Xanthopoulou, Bakker, Demerouti, and Schaufeli [48] extended the conceptualization of the JD- $R$ to include the influence of personal resources on engagement. Personal resources have been defined as state-like aspects of the self that, in part, determine an individual's ability to impact or control their environment [49]. Personal resources such as self-efficacy, resilience, optimism, and meaning-making have been shown, in part, to mediate the influence of job resources on engagement e.g., [48,50].

As previously noted, the JCM explicitly identifies meaningful work as a critical psychological state that mediates the relationship between job characteristics and motivational and performance outcomes. Along similar lines, meaningful work within the JD-R context can be considered as a personal or psychological resource that can also explain the relationship between job resources and motivational and performance outcomes. Consistent with the original conceptualization of the psychological conditions that Kahn [24] proposed are a prerequisite for the experience of engagement, May, Gilson, and Harter [27] found that the personal resources of meaningfulness, psychological safety, and resource availability had a significant influence on employee engagement. Work meaningfulness had a much 
stronger positive influence on engagement than psychological safety or resource availability. In general, given the significant overlap between job characteristics in the JCT and job resources in the JD-R, the partial mediating relationship between meaningful work and employee engagement within the JD-R context warrants further investigation.

Researchers have shown that meaningful work results in a number of important attitudinal and motivational outcomes. Meaningfulness has been associated with psychological well-being [51]; greater commitment, satisfaction, and involvement [52]; increased work motivation [31,42]; and lower absenteeism [53]. Numerous researchers have also shown that meaningfulness and connection to purpose are related to work engagement e.g., [27,54]. May, Gilson and Harter [27], for example, showed using path analysis that meaningful work also had a strong association with engagement $(\beta=0.73)$. By way of explanation, Albrecht [29], arguing from a JD-R perspective, suggested that employees who understand the value and purpose of their work are more likely to be energized, motivated, and engaged. In effect, meaningfulness provides the psychological bridge that connects an employee's experience of their work and their level of engagement [10]. Along similar lines, Kahn [24] proposed that psychological meaningfulness derives from jobs that provide challenging work, that require the use of varied skills, and that allow employees to feel they make a valuable contribution. As such, these employees will not only feel that they are able to give to others and to their organization, but also feel that they receive the support and resources they require to successfully perform their roles and to personally connect and engage with their work on a deeper level.

\section{Employee Engagement}

Since its emergence in the 1990s, various definitions of employee engagement have been proposed. Kahn [24] posited that engagement is "the harnessing of organization members' selves to their work roles; in engagement, people employ and express themselves physically, cognitively, and emotionally during role performances" (p. 694). Schaufeli, Salanova, Gonzalez-Roma, and Bakker ([55], p. 74) in what is the most widely cited academic definition of engagement, proposed that engagement is "a positive, fulfilling, work-related state of mind that is characterized by vigour, dedication, and absorption". Schaufeli et al. [55] proposed that vigor refers to high levels of energy and persistence in the face of adversity; dedication refers to a sense of involvement with and pride toward work; and absorption refers to being happily engrossed in one's work to the point where time passes quickly. The Utrecht Work Engagement Scale (UWES) [56] and subsequent shorter versions $[57,58]$ have been shown to be valid and reliable measures of work engagement across multiple cross-sectional and longitudinal studies.

It is well established in the research literature that employee engagement is associated with a number of desirable individual, team, and organizational outcomes $[12,17,19,59]$. Specifically, engaged workers have greater job satisfaction and commitment e.g., [43,60], less turnover intentions [61], greater organizational citizenship behavior [59], and improved health [45]. Engagement has also been associated with increased performance [62] and company financial outcomes [49]. Given that engagement has been shown to have such a broad range of positive individual, team, and organizational outcomes, organizations need to understand how they can confidently cultivate and maintain employee engagement. Meaningful work may well provide an important explanatory mechanism that in part explains the association between job resources and employee engagement.

\section{Present Study}

Despite a seemingly obvious conceptual relationship between employee engagement and meaningfulness, additional empirical research on the relationship between the constructs needs to be conducted. Up until now, and to a large extent, the constructs have been the subject of research that has been conducted on separate paths [29]. As a result, the proposed research model (see Figure 1) shows meaningful work partially mediating the relationship between job resources and employee engagement. 


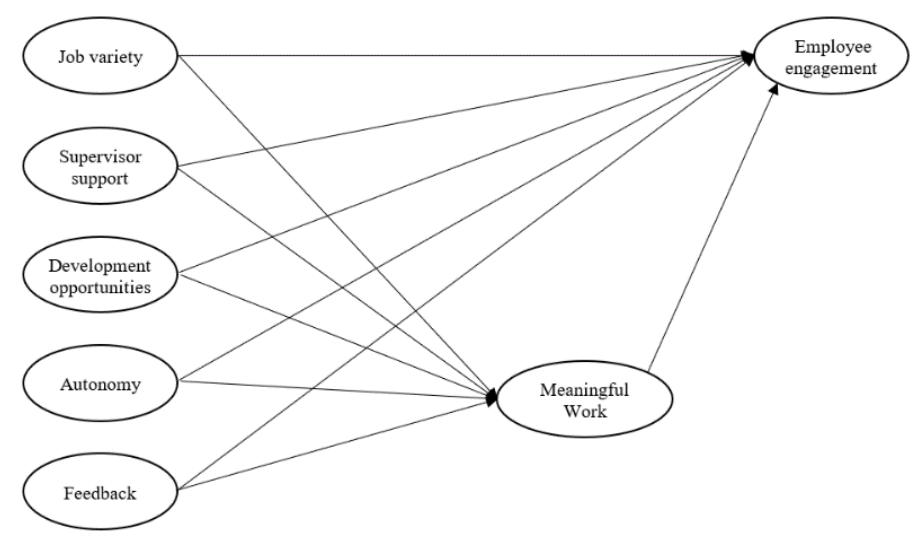

Figure 1. Proposed structural model.

In line with JD-R literature, it proposed that job resources (job variety, supervisor support, development opportunities, autonomy, and feedback) will have a direct influence on employee engagement, but also an indirect effect through work meaningfulness. It is also proposed that work meaningfulness will have a direct influence on engagement. A secondary aim of the research is to determine the relative influence of the individual job resources so as to help determine which resources may be the most effective drivers for increasing meaningful work and employee engagement.

\section{Method}

Participants: Participants were recruited from the large client database of an Australian consulting firm, who consented to receiving emails inviting them to participate in research. The email invitation informed potential participants that their results would be anonymous, and that their data would only be used for research and consulting purposes. The use of the data for the study was approved by the first author's Human Ethics Advisory Group.

The final sample consisted of 2681 participants from a range of industries and occupations. The inclusion criteria required participants to be at least 18 years of age and to have worked at least $20 \mathrm{~h}$ per week in an organization for more than three months. Of the 1573 participants who reported their gender, 812 were male $(51.6 \%)$ and 761 were female $(48.4 \%)$. Of those who reported both age and gender, the average age was 49.6 years for males $(\mathrm{SD}=10.8)$ and 43.1 years $(\mathrm{SD}=11.2)$ for females. A broad range of occupational groupings and industry sectors were represented (e.g., local government $9 \%$, education and training $10 \%$, state government $9 \%$, health care $7.5 \%$, and professional, scientific, and technical services $7.5 \%$ ).

Measures: As shown in Figure 1, seven first-order constructs were included in the proposed model: meaningful work, employee engagement, job variety, supervisor support, development opportunities, autonomy, and feedback. All items required participants to respond in relation to their experiences at work.

Meaningful Work: Meaningful work was measured using four items adapted from May, Gilson, and Harter [27] and Spreitzer [34] on a seven-point Likert scale ranging from strongly disagree (1) to strongly agree (7). An example item includes: "The things I do at work are important to me".

Employee engagement: Employee engagement was measured using the nine-item version of the Utrecht Work Engagement Scale (UWES-9) [57]. The measure uses a seven-point Likert scale ranging from never (0) to always/every day (6). Although engagement was originally theorized to consist of three sub-dimensions (vigor, dedication, and absorption), an overall engagement score was used for the present study. Schaufeli and Bakker [61] endorsed the use of the unidimensional measure, and Cronbach's alphas between 0.85 and 0.92 for the composite scale have been reported in numerous studies conducted in a range of different countries [57,58]. 
Job resources: Twenty-nine items were used to measure the five job resources used in the current research. All five job resources have been identified in meta-analyses to be among the strongest predictors of engagement e.g., [17]. Job variety was measured using five items adapted from a scale developed by Morgeson and Humphrey [63]. An example item is "I do a wide range of tasks at work". Supervisor support was measured using six items also adapted from Morgeson and Humphrey [63]. An example item is "The person I report to is supportive of me". Development opportunity was measured using six items adapted from Bakker et al. [62]. An example item is "I get lots of opportunities to improve my skills at work". Autonomy was measured using six items adapted from Spreitzer's [34] empowerment scale. An example item is "The person I report to allows me to make my own decisions". Feedback was measured using six items adapted from Karasek [64] and was related to performance feedback from a manager. An example item is "The person I report to gives me clear performance feedback about my work". All items were measured using a seven-point Likert scale ranging from strongly disagree (1) to strongly agree (7).

\section{Procedure}

The consulting firm sent an email containing a URL link to their past and current clients inviting them to complete an online survey about their experience of work. A subset of 42 items directly relevant to the proposed model (see Figure 1) was used for the current study. The survey also contained additional items relating to personality, workplace attitudes, and behavior that were not directly relevant to the research questions implicit in Figure 1.

Data screening processes indicated missing data ranging from $5.1 \%$ to $37.6 \%$ across variables. Little's [65] missing completely at random (MCAR) test indicated that the data were missing completely at random $\left(\chi^{2}=6764.11, \mathrm{df}=6671, p=0.21\right)$. Given that bootstrap testing of mediation effects in AMOS v25 require complete cases, analyses were conducted on the 1415 complete cases contained within the data set. The use of 1415 complete cases clearly exceeded the recommended minimum of 200 cases required to test the model with acceptable statistical power $[66,67]$. The small number of outliers found in the data were retained, given that the use of bootstrapping procedures that help protect against distributional non-normality and given that structural equation modelling (SEM) is considered robust to minor violations of non-normality in relatively large samples [68].

\section{Results}

\subsection{Data Analysis}

As recommended by Anderson and Gerbing [69], a two-stage approach was applied to the analyses. Although the validity of the same or similar measures had previously been established through other research, confirmatory factor analysis (CFA) in AMOS version 25 was conducted to assess the goodness of fit for the measurement model. Secondly, SEM was used to assess the fit of the proposed model and the structural relationships between the constructs. As per recommended practice [70], a range of fit indices was used to assess model fit: $\chi 2 / \mathrm{df}$ ratio $<5$ [71], CFI $\geq 0.95$ [72], RMSEA $\leq 0.05$ (point estimates and confidence intervals between 0.05 and 0.08 indicate an acceptable model fit [70]), and SRMR $\leq 0.08$ [72].

\subsection{Measurement Model}

The proposed measurement model, with each construct modelled as a first-order construct, did not yield a fully acceptable fit: $\chi^{2}=5640.42, \mathrm{df}=798, \chi^{2} / \mathrm{df}=7.07, \mathrm{CFI}=0.94$, RMSEA $=0.066$ (90\% CI: 0.064, 0.067), SRMR $=0.04$. As per recommendations by Anderson and Gerbing [69], the model was re-specified based on an examination of the modification indices as reported in the AMOS output. Three items were deleted from the employee engagement scale, and one item was deleted from each of the job variety, social support, development opportunities, autonomy, and feedback scales. The respecified model yielded an improved and acceptable fit, with all indices at their recommended 
criterion $\left(\chi^{2}=2252.70, \mathrm{df}=506, \chi^{2} / \mathrm{df}=4.45, \mathrm{CFI}=0.97, \mathrm{RMSEA}=0.049\right.$ (90\% CI: 0.047, $0.051)$, SRMR $=0.03)$. Standardized loadings across all items for the respecified model were between 0.56 and 0.96 . The means, standard deviations, internal consistency reliabilities, and correlations for the re-specified measurement model are shown in Table 1. Although four of the correlations were 0.70 or above, the square root of the average variance extracted (AVE) for each construct exceeded that of inter-construct correlations, providing support for discriminant validity [73].

Table 1. Means, standard deviations, correlations, and Cronbach's alpha of latent variables.

\begin{tabular}{cccccccccc}
\hline & $\mathbf{M}$ & SD & $\mathbf{1}$ & $\mathbf{2}$ & $\mathbf{3}$ & $\mathbf{4}$ & $\mathbf{5}$ & $\mathbf{6}$ \\
\hline 1. Employee engagement & 4.14 & 1.11 & 0.91 & & & & & & \\
2. Meaningful Work & 5.83 & 1.06 & 0.74 & 0.92 & & & & \\
3. Job variety & 5.67 & 1.25 & 0.55 & 0.62 & 0.96 & & & \\
4. Supervisor support & 5.27 & 1.41 & 0.43 & 0.35 & 0.22 & 0.96 & & \\
5. Development opportunities & 5.30 & 1.23 & 0.63 & 0.60 & 0.53 & 0.51 & 0.96 & \\
6. Autonomy & 5.16 & 1.47 & 0.47 & 0.39 & 0.29 & 0.78 & 0.47 & 0.98 \\
7. Feedback & 4.46 & 1.61 & 0.47 & 0.31 & 0.22 & 0.82 & 0.50 & 0.70 & 0.97 \\
\hline
\end{tabular}

Note: Cronbach's alpha reliabilities are shown in italics on the diagonal. All correlations are significant at $p<0.001$. The numbers in the first row of the table correspond to the numbers associated with each construct in the first column of the table.

Furthermore, testing for common method variance (CMV) using procedures recommended by Podsakoff, MacKenzie, and Podsakoff [74] showed that after the addition of a common latent factor, the decrease in standardized loadings ranged from 0.026 to 0.390 across the full set of 34 items included in the model. Overall, given that the average decrease in standardized loadings was a very modest 0.11 (with 25 items having decreases of 0.15 or less and only two having a decrease of 0.25 or larger), and given that all factor loadings remained statistically significant $(p<0.001)$, the influence of method effects can, to a large extent, be discounted $[74,75]$.

\subsection{Structural Model}

Having established a measurement model with acceptable fit, SEM was conducted to test the proposed relationships between the latent constructs using maximum likelihood estimations. The structural model yielded good fit $\left(\chi^{2}=2252.70, \mathrm{df}=506, \chi^{2} / \mathrm{df}=4.45\right.$, $\mathrm{CFI}=0.97$, RMSEA $=0.049$, SRMR $=0.03$ ). However, given that the parameters from both supervisor support and feedback to meaningful work were both non-significant, a more parsimonious respecified model was estimated with the non-significant parameters omitted. Although the chi-square ratio exceeded the generally accepted criterion, an examination of the recommended range of fit indices again indicated acceptable fit $\left(\chi^{2}=2255.65, \mathrm{df}=508\right.$, $\chi^{2} / \mathrm{df}=4.44, \mathrm{CFI}=0.97$, RMSEA $=0.049$, SRMR $=0.03$ ). The respecified model was therefore preferred on the basis of it being more parsimonious.

As shown in Figure 2, job variety, development opportunities, autonomy, and feedback were all positively associated with employee engagement. However, despite a positive bivariate correlation (see Table 1), supervisor support was negatively associated with employee engagement. The potential for multi-collinearity and suppressor effects to explain the negative parameter estimate is explained in the discussion section below. As proposed, job variety, development opportunities, and autonomy were all positively associated with meaningful work. The model explained a sizable proportion of variance in both meaningful work (49\%) and in employee engagement (65\%).

To determine whether meaningful work partially mediated the relationship between job resources (job variety, development opportunities, and autonomy) and employee engagement, bootstrapping procedures were conducted [76]. Each of the three job resources were found to have a positive indirect effect on employee engagement through meaningfulness. The standardized indirect effects from job variety, development opportunities, and autonomy to engagement via meaningfulness were as follows: $\beta=0.21, p<0.05$, 
(95\% confidence interval: $0.17-0.26$ ); $\beta=0.16, p<0.05$ (95\% CI: $0.12-0.20$ ); $\beta=0.06, p<0.05$ (95\% CI: 0.04-0.09), respectively.

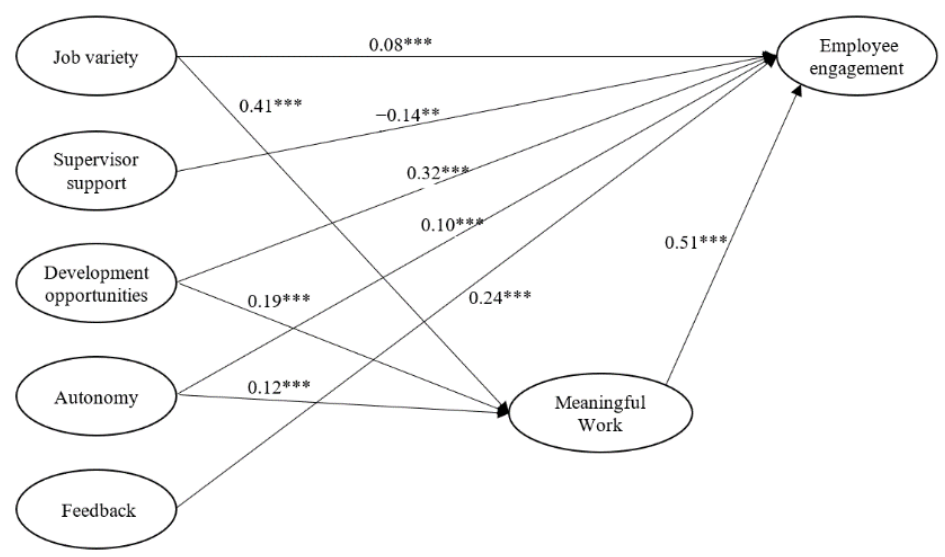

Figure 2. Final re-specified structural model with standardized maximum likelihood parameter estimates $\left(^{* * *}=p<0.001\right)$.

\section{Relative Importance of Predictors in Employee Engagement and Meaningfulness}

A post hoc relative weights analysis (RWA) [77] was conducted to determine which predictors were more important than others. Overall, the RWA regression model explained $57 \%$ of the variance in employee engagement. Meaningfulness was the most important predictor explaining $39 \%$ of the total variance, followed by development opportunities $(20 \%)$, job variety $(18 \%)$, feedback $(9 \%)$, autonomy $(8 \%)$, and supervisor support $(5 \%)$. The relative weights of all six variables were significantly greater than zero. The relative weight of meaningful work was significantly different from the weights of all other predictors.

RWA analyses were also conducted to determine which of the job resources (job variety, development opportunities, and autonomy) were the strongest predictors of meaningfulness. The RWA regression model explained $45 \%$ of the variance in meaningfulness with job variety accounting for $49 \%$ of the total variance, followed by development opportunities $(37 \%)$ and autonomy (14\%). The weights of all three predictors were significantly greater than zero. The relative weight of both job variety and development opportunities was significantly different from that of autonomy.

\section{Discussion}

\subsection{Work Meaningfulness}

The current research examined the viability of expanding the JD-R model to include meaningful work as a mediator between job resources and employee engagement. As proposed, and consistent with theorizing by Kahn [24], work meaningfulness had a strong positive relationship with employee engagement. Furthermore, the relationship between meaningfulness and engagement was significantly stronger than the relationships between each of the five job resources included in the model and engagement. The results are therefore in line with only a limited number of studies that have empirically demonstrated a relationship between work meaningfulness and employee engagement e.g., [27], and with the numerous studies showing moderately strong relationships between job resources and employee engagement e.g., $[17,45]$.

With respect to work meaningfulness as the psychological mechanism by which resources influence engagement, three of the five job resources modelled (job variety, development opportunities, and autonomy) had a significant and indirect positive relationship with employee engagement through meaningfulness. The findings therefore contribute to the literature by highlighting the importance of work meaningfulness within a JD-R context and as a psychological mechanism through which job resources, in part, exert their positive influence on employee engagement. RWA analyses showed that job variety and 
development opportunities were the strongest predictors of meaningfulness, explaining $49 \%$ and $37 \%$ of the total variance, respectively. The results therefore suggest that employees who experience more job variety, development opportunities, and to a lesser extent, autonomy, in their work roles are more likely to frame their work within a broader context and to experience their work to be more meaningful. As a result, employees will feel like they have a greater sense of purpose in their work [24] and, thus, approach their work with more vigor, dedication, and absorption [55].

The results provide an intrinsic motivational explanation of how certain job resources or job characteristics influence employee experiences of meaningfulness and engagement. Beyond JCT and JD-R, the results also align with a number of alternative well-established theories. Self-determination theory [39], for example, explains that the satisfaction of autonomy, competence, and relatedness needs will result in higher levels of intrinsic motivation and the experience of work as meaningful [29]. Task variety, for example, may foster meaningfulness through competence by providing opportunities for intellectual stimulation, skill development, and by helping employees to more fully understand the broader context of their work. The results also support the work of Kahn [24], who posited that meaningfulness stems from work that requires the use of varied skills, which in turn fosters employee engagement. These results are also in line with regulatory focus theory [78], in that employees who are provided with development opportunities are more likely to think about future aspirations, understand the broader implications of their work, and experience engagement.

The results showed that neither supervisor support nor supervisor feedback were significant predictors of meaningful work, despite their significant bivariate associations with the construct and in contrast to the similar associations previously reported in the literature e.g., [43]. It may therefore be the case that employees experience less meaningfulness when job resources are provided by managers rather than being self-directed or "crafted" [33] within their work role. The receipt of feedback from a manager might prompt employees to feel obligated to improve their performance based on the feedback, therefore potentially diminishing positive affect and work meaningfulness. Additionally, it might be the case that when employees experience support from a supervisor, they view the interaction as part of a formal relationship that is formalized by organizational structure, rather than as an authentic interaction that contributes to the purpose and meaning of their work.

\subsection{Job Resources and Employee Engagement}

In partial support of JD-R theory [79], and as previously noted, four of the job resources (job variety, development opportunities, autonomy, and feedback) had a significant, direct positive relationship with employee engagement. The results therefore indicate that organizations that provide these resources are more likely to have engaged employees.

Contrary to expectations, supervisor support was found in the modelling to have a significant negative association with employee engagement, despite the positive bivariate correlation between the variables. Furthermore, in contrast to expectations, Mengue, Auh, Fisher, and Haddad [80] found that supervisor support was not positively or significantly associated with engagement. Mengue et al. [80] argued that the inclusion of other resources may be sufficient to foster engagement and that co-workers, rather than supervisors, may be a more valuable source of social support when employees are provided with a range of resources. Furthermore, the high bivariate correlation $(r=0.82)$ between supervisor support and supervisor feedback could offer an explanation for the unexpected negative relationship. Even though discriminant validity was established between supervisor support and supervisor feedback, the high correlation suggests that multicollinearity may have been an issue in the SEM, resulting in a reversal of the direction of the relationship between social support and employee engagement [81]. Additionally, a suppressor effect offers a potential statistical explanation for the unexpected relationship whereby the inclusion of supervisor support strengthened the influence of another predictor in the model, causing supervisor support to become negatively associated with engagement [82]. A common 
method for identifying suppressor variables involves systematically deleting predictor variables from the model [82]. A post hoc analysis revealed that the relationship between supervisor support and employee engagement became positive, albeit non-significant, once supervisor feedback was removed from the model.

\subsection{Practical Implications}

The results suggest that fostering meaning and purpose for employees in the workplace may present an opportunity for organizations to enhance employee engagement. For example, empowerment programs aimed at increasing decision-making and autonomy in the workplace could be implemented as a useful intervention. Furthermore, conducting development conversations with employees could ensure that they are provided with opportunities to enhance their skills and are able to experience a variety of challenges in their role. These types of interventions would target meaningfulness through the provision of job resources.

Other interventions aimed directly at fostering meaningfulness in the workplace could be implemented, such as aspirations, values, and strengths conversations, to gain a deeper understanding of what drives employees. Employees might also be encouraged and trained to engage in job crafting whereby they can effectively focus on changing characteristics of their job and relationship with others to suit their personal preferences [29]. Furthermore, employee roles and tasks could be explicitly linked with the larger mission and purpose of the organization to promote an understanding of the "bigger picture". The results of this study also highlight the need for further research to understand how organizations (e.g., through alternative personal resources and job resources) can best develop meaningfulness for their employees.

\section{Limitations and Future Directions}

It is well established that cross-sectional designs limit the extent to which causal relationships can be established from the findings. Despite SEM providing insight into the likely direction of the relationships, future research using longitudinal data is recommended. A further limitation is the use of self-report measures, rather than more objective measures such as ratings of behaviors. Cross-sectional self-report data bring the prospect of common method bias, whereby variance in the proposed model results from measurement method as opposed to true variance in the statistical model [74]. However, self-report data are generally regarded as an appropriate measure of employee perceptions [83,84], and for the current case, it would be difficult to accurately assess employee perceptions of work engagement and work meaningfulness using objective measures.

In terms of future research opportunities, and beyond the need to collect longitudinal data, organization-level perspectives could usefully be incorporated in the model. For example, the impact of organizational resources, such as culture, climate, and Human Resource policies on meaningfulness and engagement, could usefully be explored [85], as could the impact of corporate responsibility initiatives [86]. Additional personal resources such as PsyCap [87] could also be considered in future research as there is a growing body of evidence to support the relationship between PsyCap and employee engagement e.g., [49]. Furthermore, the complete JD-R model could usefully be tested to include the impact of job demands in relation to burnout. Finally, it would be useful to explore the experience of meaningfulness across different industries or sectors. For instance, it would be interesting to investigate whether jobs in not-for-profit and medical contexts inherently provide a heightened sense of meaning for employees.

\section{Conclusions}

Overall, despite meaningful work previously being recognized as a central variable within the work context e.g., [24,29], there has been limited empirical research on meaningful work as a psychological mechanism accounting for the influence of job resources on employee engagement. The present study highlights the importance of meaningful 
work as a mediator within the JD-R model explaining, in part, how the experience of job resources results in the experience of engagement. As meaningfulness was found to be the strongest predictor of employee engagement, future research and interventions should focus on how meaningful work can be cultivated in the workplace, in particular, through the provision of context appropriate job resources.

Author Contributions: Writing-original draft preparation, S.L.A. and C.R.G.; formal analysis, S.L.A. and C.R.G.; writing-review and editing, S.L.A. and C.R.G.; conceptualization, S.L.A. and A.M.; data collection, A.M. and S.L.A. All authors have read and agreed to the published version of the manuscript.

Funding: This research received no external funding.

Institutional Review Board Statement: The study was approved by the Ethics Committee of Deakin University (DUHREC 2014-292) and adheres to the Australian Codes for the Responsible and Ethical Conduct of Research.

Informed Consent Statement: Informed consent was obtained from all subjects involved in the study.

Data Availability Statement: Not applicable.

Conflicts of Interest: The authors declare no conflict of interest.

\section{References}

1. Wrzesniewski, A. Finding positive meaning in work. In Positive Organizational Scholarship; Cameron, K.S., Dutton, J.E., Quinn, R.E., Eds.; Berrett-Koehler: San Francisco, CA, USA, 2003; pp. 296-308.

2. Luthans, F. The need for and meaning of positive organizational behaviour. J. Organ. Behav. 2002, 23, 695-706. [CrossRef]

3. Linley, P.A.; Harrington, S.; Garcea, N. Oxford Handbook of Positive Psychology and Work; Oxford University Press: Oxford, UK, 2010.

4. Aguinis, H.; Glavas, A. On corporate social responsibility, sensemaking, and the search for meaningfulness through work. J. Manag. 2019, 45, 1057-1086. [CrossRef]

5. Glavas, A. Corporate social responsibility and employee engagement: Enabling employees to employ more of their whole selves at work. Front. Psychol. 2016, 7, 796. [CrossRef] [PubMed]

6. Westerman, J.W.; Rao, M.B.; Vanka, S.; Gupta, M. Sustainable human resource management and the triple bottom line: Multistakeholder strategies, concepts, and engagement. Hum. Resour. Manag. Rev. 2020, 30, 100742. [CrossRef]

7. Fletcher, L.; Schofield, K. Facilitating meaningfulness in the workplace: A field intervention study. Int. J. Hum. Resour. Manag. 2019. [CrossRef]

8. Albrecht, S.L. Meaningful work: Some key questions for research and practice. In Flourishing in Life, Work and Careers: Individual Wellbeing and Career Experiences; Burke, R.J., Page, K.M., Cooper, C.L., Eds.; Edward Elgar: Cheltenham, UK, 2015 ; pp. $210-234$.

9. Lysova, E.I.; Allan, B.A.; Dik, B.J.; Duffy, R.D.; Steger, M.F. Fostering meaningful work in organizations: A multi-level review and integration. J. Vocat. Behav. 2009, 110, 374-389. [CrossRef]

10. Steger, M.F.; Dik, B.J. Work as meaning: Individual and organizational benefits of engaging in meaningful work. In Oxford Handbook of Positive Psychology and Work; Linley, P.A., Harrington, S., Garcea, N., Eds.; Oxford University Press: Oxford, UK, 2010; pp. 131-142.

11. Macey, W.H.; Schneider, B.; Barbera, K.M.; Young, S.A. Employee Engagement: Tools for Analysis, Practice, and Competitive Advantage; Wiley: Hoboken, NJ, USA, 2009.

12. Macey, W.H.; Schneider, B. The meaning of employee engagement. Ind. Organ. Psychol. 2008, 1, 3-30. [CrossRef]

13. Salanova, M.; Bakker, A.B.; Llorens, S. Flow at work: Evidence for an upward spiral of personal and organizational resources. J. Happiness Stud. 2006, 7, 1-22. [CrossRef]

14. Saks, A. Antecedents and consequences of employee engagement revisited. J. Organ. Eff. People Perform. 2019, 6, 19-38. [CrossRef]

15. Schneider, B.; Yost, A.; Kropp, A.; Kind, C.; Lam, H. Workforce engagement: What it is, what drives it, and why it matters for organizational performance. J. Organ. Behav. 2017, 39, 462-480. [CrossRef]

16. Bakker, A.B.; Demerouti, E. The job demands-resources model: State of the art. J. Manag. Psychol. 2007, 22, 309-328. [CrossRef]

17. Crawford, E.R.; LePine, J.A.; Rich, B.L. Linking job demands and resources to employee engagement and burnout: A theoretical extension and meta-analytic test. J. Appl. Psychol. 2010, 95, 834-848. [CrossRef] [PubMed]

18. Kwon, K.; Kim, T. An integrative literature review of employee engagement and innovative behavior: Revisiting the JD-R model. Hum. Resour. Manag. Rev. 2020, 30, 100704. [CrossRef]

19. Lesener, T.; Gusy, B.; Jochmann, A.; Wolter, C. The drivers of work engagement: A meta-analytic review of longitudinal evidence. Work Stress 2019, 34, 1-20. [CrossRef]

20. Bailey, C.; Madden, A.; Alfes, K.; Fletcher, L. The meaning, antecedents and outcomes of employee engagement: A narrative synthesis. Int. J. Manag. Rev. 2017, 19, 31-53. [CrossRef] 
21. Christian, M.S.; Garza, A.S.; Slaughter, J.E. Work engagement: A quantitative review and test of its relations with task and contextual performance. Personal. Psychol. 2011, 64, 89-136. [CrossRef]

22. Bakker, A.B.; Demerouti, E. Towards a model of work engagement. Career Dev. Int. 2008, 13, 209-223. [CrossRef]

23. King, L.A.; Hicks, J.A.; Krull, K.; Del Gaiso, A.K. Positive affect and the experience of meaning in life. J. Personal. Soc. Psychol. 2006, 90, 179-196. [CrossRef]

24. Kahn, W.A. Psychological conditions of personal engagement and disengagment at work. Acad. Manag. J. 1990, 33, 692-724.

25. Cartwright, S.; Holmes, N. The meaning of work: The challenge of regaining employee engagement and reducing cynicism. Hum. Resour. Manag. Rev. 2006, 16, 199-208. [CrossRef]

26. Han, S.-H.; Sung, M.; Suh, B. Linking meaningfulness to work outcomes through job characteristics and work engagement. Hum. Resour. Dev. Int. 2020. [CrossRef]

27. May, D.R.; Gilson, R.L.; Harter, L.M. The psychological conditions of meaningfulness, safety and availability and the engagement of the human spirit at work. J. Occup. Organ. Psychol. 2004, 77, 11-37. [CrossRef]

28. Soane, E.; Shantz, A.; Alfes, K.; Truss, C.; Rees, C.; Gatenby, M. The association of meaningfulness, well-being, and engagement with absenteeism: A moderated mediation model. Hum. Resour. Manag. 2013, 52, 441-456. [CrossRef]

29. Albrecht, S.L. Work engagement and the positive power of meaningful work. In Advances in Positive Organizational Psychology; Bakker, A.B., Ed.; Emerald: Bingley, UK, 2013; Volume 1, pp. 237-260.

30. Eagleton, T. The Meaning of Life: A Very Short Introduction; Oxford University Press: Oxford, UK, 2007.

31. Hackman, J.R.; Oldham, G.R. Work Redesign; Addison-Wesley: Boston, MA, USA, 1980.

32. Hackman, J.R.; Oldham, G.R. Motivation through the design of work: Test of a theory. Organ. Behav. Hum. Perform. 1976, 16, 250-279. [CrossRef]

33. Wrzesniewski, A.; LoBuglio, N.; Dutton, J.E.; Berg, J.M. Job crafting and cultivating positive meaning and identity in work. In Advances in Positive Organizational Psychology; Bakker, A.B., Ed.; Emerald: Bingley, UK, 2013; Volume 1, pp. $281-302$.

34. Spreitzer, G.M. Psychological empowerment in the workplace: Construct definition, measurement, and validation. Acad. Manag. J. 1995, 38, 1442-1465.

35. Cardador, M.T.; Rupp, D.E. Organizational culture, multiple needs, and the meaningfulness of work. In Handbook of Organizational Culture and Climate, 2nd ed.; Ashkanasy, N.M., Wilderom, C.P.M., Peterson, M.P., Eds.; Sage: Thousand Oaks, CA, USA, 2011; pp. $158-180$.

36. Rothman, S.; Hamukang'andu, L. Callings, work role fit, psychological meaningfulness and work engagement among teachers in Zambia. South Afr. J. Educ. 2013, 33, 1-16. [CrossRef]

37. Maslow, A.H. Motivation and Personality, 2nd ed.; Harper and Row: New York, NY, USA, 1970.

38. McClelland, D.C. The Achieving Society; Collier-Macmillan: New York, NY, USA, 1961.

39. Deci, E.L.; Ryan, R.M. The 'what' and 'why' of goal pursuits: Human needs and the self-determination of behavior. Psychol. Inq. 2000, 11, 227-268. [CrossRef]

40. Fredrickson, B.L. The role of positive emotions in positive psychology. Am. Psychol. 2001, 56, 218-226. [CrossRef]

41. Allan, B.A. Task significance and meaningful work: A longitudinal study. J. Vocat. Behav. 2017, 102, 174-182. [CrossRef]

42. Allan, B.A.; Batz-Barbarich, C.; Sterling, H.M.; Tay, L. Outcomes of meaningful work: A meta-analysis. J. Manag. Stud. 2019 56, 500-528. [CrossRef]

43. Humphrey, S.E.; Nahrgang, J.D.; Morgeson, F.P. Integrating motivational, social, and contextual work design features: A metaanalytic summary and theoretical extension of the work design literature. J. Appl. Psychol. 2007, 92, 1332-1356. [CrossRef] [PubMed]

44. Clausen, T.; Borg, V. Job demands, job resources and meaning at work. J. Manag. Psychol. 2011, 26, 665-681. [CrossRef]

45. Halbesleben, J.R.B. A meta-analysis of work engagement: Relationships with burnout, demands, resources, and consequences. In Work Engagement: A Handbook of Essential Theory and Research; Bakker, A.B., Leiter, M.P., Eds.; Psychology Press: New York, NY, USA, 2010; pp. 102-117.

46. Fairlie, P. Meaningful work, employee engagement, and other key employee outcomes: Implications for Human Resource Development. Adv. Dev. Hum. Resour. 2011, 13, 508-525. [CrossRef]

47. Rosso, B.D.; Dekas, K.H.; Wrzesniewski, A. On the meaning of work: A theoretical integration and review. Res. Organ. Behav. 2010, 30, 91-127. [CrossRef]

48. Xanthopoulou, D.; Bakker, A.B.; Demerouti, E.; Schaufeli, W.B. The role of personal resources in the job demands-resources model. Int. J. Stress Manag. 2007, 14, 121-141. [CrossRef]

49. Xanthopoulou, D.; Bakker, A.B.; Demerouti, E.; Schaufeli, W.B. Reciprocal relationships between job resources, personal resources, and work engagement. J. Vocat. Behav. 2009, 74, 235-244. [CrossRef]

50. Van den Heuvel, M.; Demerouti, E.; Schaufeli, W.B.; Bakker, A.B. Personal resources and work engagement in the face of change. In Contemporary Occupational Health Psychology: Global Perspectives on Research and Practice; Houdmont, J., Leka, S., Eds.; John Wiley \& Sons Ltd.: Hoboken, NJ, USA, 2010; pp. 124-150.

51. Zika, S.; Chamberlain, K. On the relation between meaning in life and psychological well-being. Br. J. Psychol. 1992, 83, 133-145. [CrossRef]

52. Milliman, J.F.; Czaplewski, A.J.; Ferguson, J.M. Workplace spirituality and employee work attitudes: An exploratory empirical assessment. J. Organ. Change Manag. 2003, 16, 426-447. [CrossRef] 
53. Wrzesniewski, A.; McCauley, C.; Rozin, P.; Schwartz, B. Jobs, careers, and callings: People's relations to their work. J. Res. Personal. 1997, 31, 21-33. [CrossRef]

54. Van Tuin, L.; Schaufeli, W.B.; Van den Broeck, A.; Van Rhenen, W. A corporate purpose as an antecedent to employee motivation and work engagement. Front. Psychol. 2020, 11, 572343. [CrossRef]

55. Schaufeli, W.B.; Salanova, M.; González-Romá, V.; Bakker, A.B. The measurement of engagement and burnout: A two sample confirmatory factor analytic approach. J. Happiness Stud. 2002, 3, 71-92. [CrossRef]

56. Schaufeli, W.B.; Bakker, A.B. UWES-Utrecht Work Engagement Scale: Test Manual, 2004; Department of Psychology, Utrecht University: Utrecht, The Netherlands, 2004.

57. Schaufeli, W.B.; Bakker, A.B.; Salanova, M. The measurement of work engagement with a short questionnaire - A cross national study. Educ. Psychol. Meas. 2006, 66, 701-716. [CrossRef]

58. Schaufeli, W.B.; Shimazu, A.; Hakanen, J.; Salanova, M.; De Witte, H. An ultra-short measure for work engagement: The UWES-3 validation across five countries. Eur. J. Psychol. Assess. 2019, 35, 577-591. [CrossRef]

59. Saks, A.M. Antecedents and consequences of employee engagement. J. Manag. Psychol. 2006, 21, 600-619. [CrossRef]

60. Harter, J.K.; Schmidt, F.L.; Hayes, T.L. Business-unit-level relationship between employee satisfaction, employee engagement, and business outcomes: A meta-analysis. J. Appl. Psychol. 2002, 87, 268-279. [CrossRef]

61. Schaufeli, W.B.; Bakker, A.B. Defining and measuring work engagement: Bringing clarity to the concept. In Work Engagement: $A$ Handbook of Essential Theory and Research; Bakker, A.B., Leiter, M.P., Eds.; Psychology Press: Hove, UK, 2010; Volume 8, pp. 10-24.

62. Bakker, A.B.; Demerouti, E.; Verbeke, W. Using the job demands-resources model to predict burnout and performance. Hum. Resour. Manag. 2004, 43, 83-104. [CrossRef]

63. Morgeson, F.P.; Humphrey, S.E. The Work Design Questionnaire (WDQ): Developing and validating a comprehensive measure for assessing job design and the nature of work. J. Appl. Psychol. 2006, 91, 1321-1339. [CrossRef]

64. Karasek, R.A. Job Content Questionnaire and User's Guide; Department of Work Environment, University of Massachusetts Lowell: Lowell, MA, USA, 1985.

65. Little, R.J. A test of missing completely at random for multivariate data with missing values. J. Am. Stat. Assoc. 1998, 83, 1198-1202. [CrossRef]

66. Cohen, J. Statistical Power Analysis for the Behavioral Sciences, 2nd ed.; Lawrence Erlbaum Associates: Mahwah, NJ, USA, 1988.

67. Soper, D.S. A-priori Sample Size Calculator for Structural Equation Models Software. 2013. Available online: http://www. danielsoper.com/statcalc (accessed on 23 January 2020).

68. Byrne, B.M. Structural Equation Modeling with AMOS: Basic Concepts, Applications, and Programming; Routledge: Oxfordshire, UK, 2016.

69. Anderson, J.C.; Gerbing, D.W. Structural equation modeling in practice: A review and recommended two-step approach. Psychol. Bull. 1988, 103, 411-423. [CrossRef]

70. Kline, R.B. Principles and Practice of Structural Equation Modeling, 3rd ed.; The Guilford Press: New York, NY, USA, 1998.

71. Marsh, H.W.; Hocevar, D. Application of confirmatory factor analysis to the study of self-concept: First-and higher order factor models and their invariance across groups. Psychol. Bull. 1985, 97, 562-582. [CrossRef]

72. Hu, L.; Bentler, P.M. Cutoff criteria for fit indexes in covariance structure analysis: Conventional criteria versus new alternatives Struct. Equ. Modeling Multidiscip. J. 1999, 6, 1-55. [CrossRef]

73. Hair, J.F.; Black, W.C.; Babin, B.J.; Anderson, R.E. Multivariate Data Analysis, 7th ed.; Prentice-Hall, Inc.: Upper Saddle River, NJ, USA, 2010.

74. Podsakoff, P.M.; MacKenzie, S.B.; Podsakoff, N.P. Sources of method bias in social science research and recommendations on how to control it. Annu. Rev. Psychol. 2012, 63, 539-569. [CrossRef] [PubMed]

75. Elangovan, A.R.; Xie, J.L. Effects of perceived power of supervisor on subordinate work attitudes. Leadersh. Dev. J. 2000, 21, 319-328. [CrossRef]

76. Preacher, K.J.; Hayes, A.F. Asymptotic and resampling strategies for assessing and comparing indirect effects in multiple mediator models. Behav. Res. Methods 2008, 40, 879-891. [CrossRef] [PubMed]

77. Tonidandel, S.; LeBreton, J.M. Relative importance analyses: A useful supplement to multiple regression analyses. J. Bus. Psychol. 2011, 26, 1-9. [CrossRef]

78. Higgins, E.T. Promotion and prevention: Regulatory focus as a motivational principle. In Advances in Experimental Psychology; Zanna, M.P., Ed.; Academic Press: Cambridge, MA, USA, 1998; Volume 30, pp. 1-46.

79. Bakker, A.B.; Demerouti, E. Job demands-resources theory. In Wellbeing: A Complete Reference Guide, Volume III, Work and Wellbeing; Chen, P.Y., Cooper, C.L., Eds.; Wiley Blackwell: Hoboken, NJ, USA, 2014; pp. 37-64.

80. Mengue, B.; Auh, S.; Fisher, M.; Haddad, A. To be engaged or not to be engaged: The antecedents and consequences of service employee engagement. J. Bus. Res. 2013, 66, 2163-2170. [CrossRef]

81. Grewal, R.; Cote, J.A.; Baumgartner, H. Multicollinearity and measurement error in structural equation models: Implications for theory testing. Mark. Sci. 2004, 23, 519-529. [CrossRef]

82. Maassen, G.H.; Bakker, A.B. Suppressor variables in path models: Definitions and interpretations. Sociol. Methods Res. 2001, 30, 241-270. [CrossRef]

83. Spector, P.E. Using self-report questionnaires in OB research: A comment on the use of a controversial method. J. Organ. Behav. 1994, 15, 385-392. [CrossRef]

84. Spector, P.E. Do not cross me: Optimizing the use of cross-sectional designs. J. Bus. Psychol. 2019, 34, 125-137. [CrossRef] 
85. Albrecht, S.L.; Bakker, A.B.; Gruman, J.A.; Macey, W.H.; Saks, A.M. Employee engagement, human resource management practices and competitive advantage. J. Organ. Eff. People Perform. 2015, 2, 7-35. [CrossRef]

86. Glavas, A.; Kelley, K. The effects of perceived corporate social responsibility on employee attitudes. Bus. Ethics Q. 2014, 24, 165-202. [CrossRef]

87. Luthans, F.; Avolio, B.J.; Avey, J.B.; Norman, S.M. Positive psychological capital: Measurement and relationship with performance and satisfaction. Pers. Psychol. 2007, 60, 541-572. [CrossRef] 